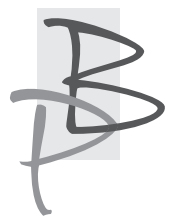

Tadeusz Bujnicki*

Warszawa

https://orcid.org/0000-0003-2343-3696

\title{
Litwa żagarystów. Między historią, mitem a współczesnością
}

Streszczenie: Artykuł koncentruje się na napięciach, jakie występowały po I wojnie światowej pomiędzy Rzeczpospolitą Polską a Litwą, szczególnie Wilnem. Ówczesne grupy artystyczne, przede wszystkim „Żagary", musiały rozwijać swą działalność w przestrzeni pełnej antagonizmów. Badacz podkreśla, że Wilno i Wileńszczyzna mogły być - i były - kolebką ruchów odradzających się kultur narodowych (litewskiej, białoruskiej) oraz istotnym ośrodkiem literatury i kultury żydowskiej (Jeruzalem Północy). Wilno było także ważnym - jak w romantyzmie czy dwudziestoleciu międzywojennym - centrum literatury polskiej.

Słowa-klucze: Wilno, żagaryści, poezja polsko-litewska, napięcia kulturowe.

Tadeusz Bujnicki - prof. zw. dr hab., em. prof. Uniwersytetu Jagiellońskiego, historyk literatury polskiej. Redaktor i współredaktor wielu tomów, w tym: (z K. Stępnikiem) Ostatni obywatele Wielkiego Księstwa Litewskiego (Lublin 2005), (z K. Biedrzyckim, J. Fazanem) Żagary. Środowisko kulturowe grupy literackiej (Kraków 2009) oraz (z J. Majchrzyk) Henryk Sienkiewicz w szkole, bibliotece i muzeum (Warszawa 2015). Autor monografii: m.in. Sienkiewicza powieści z lat dawnych: studia (Kraków 1996), Na pograniczach, kresach i poza granicami. Studia (Białystok 2014). 


\section{Lithuania of the Żagary group members. Between history, myth and modernity}

Summary: The article focuses on tensions that occurred after World War I between the Republic of Poland and Lithuania, especially Vilnius. The artistic groups of that time, first of all "Żagary", had to develop their activity in an atmosphere full of tensions and antagonisms. The researcher emphasizes that Vilnius and the Vilnius region could have been - and were - the cradle of movements of reviving national cultures (Lithuanian, Belarussian) and an important center of Jewish literature and culture (the Jersusalem of the North ). Vilnius was also an important - as in the Romanticism or the Interwar Years - center of Polish literature.

Key words: Vilnius, Polish-Lithuanian poetry, cultural tensions.

Obecność składników litewskich w utworach żagarystów stanowi istotne zagadnienie badawcze. Dla niektórych z nich był to problem tożsamości powiązanej z wieloetnicznością terytorium, dla innych - wybrane miejsce w przestrzeni, wspólny krajobraz, zróżnicowany kulturowo region, który wyodrębnia wileńską awangardę spośród innych grup podobnie przestrzennie umiejscowionych (na przykład awangarda „krakowska”, lubelski „krąg” Czechowicza). Owa swoista ,regionalność” polskiej awangardy była zarazem elementem zasadniczego napięcia: między konserwatywnością a nowoczesnością, szczególnie mocno widocznego w Wilnie:

[...] Trudno tu uwolnić się od promieniującej ze wszystkich stron, odciśniętej na ścianach domów i kościołów, historii - pisał Stanisław Bereś. - Miasto Litwinów i Polaków, Żydów i Tatarów, Białorusinów i Łotyszy, Niemców, Rosjan i Estończyków, architektoniczna perła Północy, pełna rozpasanego gotyku i baroku, o niepowtarzalnej lokalizacji geograficznej, stapiająca w religijnym tyglu katolicyzm z wyznaniem mojżeszowym, prawosławie z protestantyzmem, mahometanizm z elementami wierzeń karaimskich w jakiś nieprawdopodobny amalgamat wyznaniowy, osadzony na ciągle żywych reliktach wierzeń i kultów pogańskich; 
miasto, w którym odwiecznie krzyżowały się wpływy kultur [...]. Ta odwieczna heterogeniczność kulturowo-obyczajowych elementów składających się na specyfikę Wilna powoduje, iż istotę jego niepowtarzalności upatrywać możemy w wyjątkowej wręcz chłonności i otwartości na przeplatające się, krzyżujące i wykluczające nawzajem wartości ${ }^{1}$.

Precyzując bliżej moment historyczny, należy uwydatnić to, iż o charakterze Wilna i Wileńszczyzny w okresie międzywojennym w dużej mierze decydował fakt wciśnięcia między trzy granice, z których dwie - litewska i ZSRR - były przedmiotem stałych konfliktów. Przejściowy twór quasi-państwowy Litwa Środkowa (1920-1922) nie rozstrzygał jeszcze o państwowej przynależności Wilna i dopiero fiasko koncepcji federacyjnej Piłsudskiego ostatecznie powoduje włączenie miasta w granice II Rzeczypospolitej. Wytwarza to trwający przez całe międzywojnie konflikt polsko-litewski. Wilno stało się wówczas „kością niezgody” między obu państwami.

W rezultacie mniejszości na Wileńszczyźnie (zwłaszcza litewska) były $\mathrm{z}$ reguły ograniczane w swoich prawach i nierzadko represjonowane. Miało to wpływ na wzmocnienie tendencji nacjonalistycznych i na radykalizację nastrojów społecznych. Warto przy tym pamiętać, że z miejską przestrzenią Wilna kontrastowała wiejska lub małomiasteczkowa przestrzeń Wileńszczyzny z własnymi wzorcami kulturowymi (i przyzwyczajeniami literackimi). Były to często wzorce kultury drobnoszlacheckiej lub chłopskiej (także litewskiej i białoruskiej). Nie sposób również zapomnieć o rozległej kulturze społeczności żydowskiej, nierzadko dominującej w małomiasteczkowych środowiskach.

Ziemiaństwo Wileńszczyzny było bardziej tradycjonalistyczne niż w reszcie Polski. Tu funkcjonowała obyczajowość zaścianka oraz relikty dawnej szlacheckiej Rzeczypospolitej. Na tym tle Wilno zepchnięte do roli prowincjonalnego miasta wojewódzkiego, używało kulturowego i historycznego dziedzictwa jako składnika dowartościowującego. Na tej podstawie pamięć historyczna - zachowana w tradycjach rodzinnych i środowiskowych, dokumentach i w zabytkach architektury - jest czynnikiem

1 S. Bereś, Ostatnia wileńska plejada. Szkice o poezji kręgu Żagarów, Warszawa 1990, s. 12-13. 
„konserwującym” przeszłość. Na tych podstawach gruntowały się elementy trwałości „życia pośmiertnego” Wielkiego Księstwa Litewskiego. Dawna stolica Księstwa, zdegradowana do statusu prowincji, stara się odzyskać znaczenie jako „stanica” kresowa Polski. Głównymi ośrodkami podtrzymania tej tradycji stały się Uniwersytet Stefana Batorego oraz powołany w 1931 roku Instytut Badań Europy Wschodniej. Jednak wyobrażenie Wielkiego Księstwa ulegało pewnym, lecz ważnym, przekształceniom. Z jednej strony było elementem wielkiego mitu romantycznego z Mickiewiczem jako postacią-symbolem. Z drugiej - wchłania pierwiastki starolitewskie, legendę giedyminowskiego Wilna oraz obraz miasta w czasach Zygmuntowskich.

Dzieje mitu Wielkiego Księstwa były procesem uformowanym w dłuższym czasie. Łączą się one z pojęciem „kresów”. W okresie, gdy Księstwo było częścią wielkiego organizmu państwowego - Rzeczypospolitej Obojga Narodów, na pewno nie określano je nazwą „kresy”. Pojęcie to jako „strażnica”, „placówka polskości”, „oblężona twierdza”, pojawiło się jako reakcja na ucisk zaborczy. Była to również odpowiedź na ruchy odrodzeniowe i separatystyczne litewskie i białoruskie oraz na idee krajowców. W tym znaczeniu „kresowość” stanowiła składnik nacjonalistycznego i polonocentrycznego myślenia, które uformowało się w kręgu Narodowej Demokracji. W dwudziestoleciu przekonanie o „północnych kresach” stawało się coraz bardziej powszechne i weszło do potocznego słownika polityki i kultury. Wilno i Wileńszczyzna są już kresami w pełnym tego słowa znaczeniu, a składniki tradycji Wielkiego Księstwa są cechami specyficznymi kresowości.

Zmieniają się zatem „dziedzice” tradycji Wielkiego Księstwa, a dzieje się to w związku z rytmem odrodzeń narodowych. Dla Litwinów i Białorusinów zagrożeniem staje się polska sfera „asymilacji kulturalnej”, zagrożenie dobitnie podkreślane zwłaszcza w pismach litewskiego odrodzenia („Auszra”). W rezultacie dziedzictwo po Wielkim Księstwie staje się osią zasadniczego sporu pomiędzy ruchem odrodzenia litewskiego a „polskimi” - historycznymi Litwinami. Pojawia się nowy, „pośmiertny” problem Wielkiego Księstwa - „Ostatni Obywatele Wielkiego Księstwa Litewskiego”. Ta nazwa zaczyna dotyczyć tych, którzy posługują się utopią dawnego państwa litewskiego (w ramach Rzeczypospolitej) i którzy swoimi cechami emotywnymi i mentalnościowymi przypisują się do formacji, która swoją pamięć 
historyczną zakotwicza w Wielkim Księstwie. Takim „Ostatnim Obywatelem” był niewątpliwie Piłsudski, i w podobny sposób swoją przynależność do Litwy uzasadniał Marian Zdziechowski². Jeszcze na początku XX wieku powstała koncepcja „kantonalnej” trójnarodowościowej (polsko-litewskobiałoruskiej) Litwy. Głosili ją tzw. „krajowcy” (Ludwik Abramowicz, Tadeusz Wróblewski, w wczesnej fazie także Michał Romer). Ku zbliżonej idei federacyjnej (Litwy połączonej unią z Polską) zmierzał Józef Piłsudski. Dla tych koncepcji problem języka był drugoplanowy - ważna stawała się przede wszystkim świadomość „litewska” w sensie historycznym i kulturowym. $\mathrm{Z}$ założenia przeciwstawiały się one mocnym w międzywojennym Wilnie tendencjom nacjonalistycznym.

Rzecz jasna, mit Wielkiego Księstwa Litewskiego zderzał się z tradycją polskości miasta, z tym, że była to polskość odrębna, ukształtowana przez aktywny w mieście ruch regionalistyczny. Jedna z czołowych regionalistek, Wanda Dobaczewska, w broszurze Dzieje kultury wileńskiej pomiędzy dwoma powstaniami pisała:

Nadaję terminowi temu [Litwa - dop. T.B.] to samo znaczenie, jakie ci obywatele niegdyś mu nadawali, mając na myśli dzielnicę dawnego Państwa Polskiego ${ }^{3}$.

Właśnie „dzielnica”, a nie odrębny byt państwowy w ramach Rzeczypospolitej Obojga Narodów. Wileńszczyzna może co prawda występować jako „mała ojczyzna” etnicznych zbiorowości, jednak najczęściej - zbiorowości polskiej i tutejszej wytworzony przez społeczność polsko-białoruską (dialekt północnokresowy) ${ }^{4}$. Badaczka Zofia Kurzowa podkreśla, iż:

2 „Różnolity narodowościowo kraj nasz stanowi część Litwy historycznej i nas [...] wychowywano jako Litwinów, oczywiście w tym znaczeniu, w jakim był nim Mickiewicz [...]. I gdyby mnie dziś zapytano, kim w głębi serca się czuję, powiedziałbym, że czuję się obywatelem W. Ks. Litewskiego nierozerwalnie złączonego unią z Polską". Idea polska na Kresach, cyt. za: J. Bardach, O dawnej i niedawnej Litwie, Poznań 1988, s. 216.

3 W. Dobaczewska, Dzieje kultury wileńskiej pomiędzy dwoma powstaniami, Wilno 1937, s. 5.

4 Z. Kurzowa, Język polski Wileńszczyzny i kresów pótnocno-wschodnich XVI-XX w., Warszawa - Kraków 1993, s. 41. 
Język polski w Wielkim Księstwie Litewskim, kształtujący się tam od chwili pierwszych kontaktów Polski z Litwą, trzeba więc pojmować nie jako część języka narodowego rozszerzoną tylko na nowe obszary polityczne, ale jako zupełnie nową jakość, powstałą ze stopienia polszczyzny z substratem miejscowym 5 .

Miało to niewątpliwy wpływ na poczucie tożsamości, wyraźnie lokalnej. Co istotne, w małym stopniu określanej przez wpływ języka litewskiego. „Litewskość” terytorium nie określała się językowo, lecz w sferze pamięci historyczno-kulturowej. Na tej podstawie w świadomości części inteligencji wileńskiej tworzyło się przekonanie o swoistej odrębności regionalnej. Nazwa „Litwin” pojmowana po mickiewiczowsku traciła sens etniczny6. Dla pisarzy regionalistów granica dzieląca ówcześnie ziemie „litewskie” miała charakter sztuczny i niesprawiedliwy. Tak na przykład rozumiała „litewskość” poetka Wanda Dobaczewska-Niedziałkowska, pisząc w „Środach Literackich” o „ranie niezagojonej”, która powstała po „rozdarciu Litwy na dwie połowy”7. Tym niemniej, Wilno i Wileńszczyzna mogły być - i były - kolebką ruchów odradzających się kultur narodowych (litewskiej, białoruskiej) oraz istotnym ośrodkiem literatury i kultury żydowskiej (Jeruzalem Północy). Wilno było także ważnym - jak w romantyzmie tak w dwudziestoleciu międzywojennym centrum literatury polskiej.

Z kolei mieszkająca w Wilnie inteligencja litewska (jej głównymi przedstawicielami byli Michał i Wincenty Birżyszkowie) zasadniczym polem walki uczyniła konieczność włączenia Wilna jako stolicy w skład powstającej Republiki Litewskiej. Działaczom litewskim chodziło o historyczną litewskość Wilna, będącego dla nich „kolebką” i „,domem”. I dlatego najważniejszą sprawą stawała się relituanizacja miasta. Owa prężna, choć niewielka, mniejszość litewska mimo ograniczeń i represji tworzyła w międzywojennym Wilnie znaczące środowisko kulturalne i literackie ${ }^{8}$.

5 Tamże, s. 40.

6 Pisał na ten temat Stanisław Cat-Mackiewicz w książce Dom Radziwiłtów, Warszawa 1990, r. Cztery znaczenia nazwy: Litwin, s. 20-31; O , litewskości” Mackiewicza zob. s. 27-28.

7 W. Dobaczewska, Stowiki litewskie, „Środy Literackie” 1936, nr 5, s. 19.

8 Por. A. Lapinskene, Vilniaus lietuviu literatura 1920-1940, Vilnius 2008. 
Jako „tygiel” wieloetniczny i wielokulturowy wytwarzało miasto zjawiska dostępne tylko zbiorowościom pogranicza. Na świadomości mieszkańców Wileńszczyzny odcisnęły piętno: sytuacja wieloetniczności i dyfuzji kultur. Z jednego punktu widzenia uzasadnione są tezy o wartości polonizacyjnych funkcji kultury polskiej, z innego - o „regresywnych” jej efektach wobec „młodych” kultur litewskiej czy białoruskiej. Jednak wieloznaczność - mimo sprzeczności i napięć - lepiej uwydatnia uniwersalne wartości kultury pogranicza, przede wszystkim rustykalnej ${ }^{9}$. Tym wyraźniej, że zderza się ona z cywilizacją miasta, odrębną i nowoczesną, ale nadal mocno ograniczoną.

Dlatego mit Wielkiego Księstwa Litewskiego można ująć z kilku różnych perspektyw. Obraz poetycki spełniał wobec niego wielorakie funkcje i nie tylko stanowił świadectwa litewskiej i białoruskiej przeszłości Wilna i Wileńszczyzny, lecz również tworzył podstawy semantyki „litewsko-białoruskiej”, pojmowanej jako stop mitu i historii. Przede wszystkim w wyobrażeniu przestrzennym, które pozwala na odczytanie poczucia związku z ziemią przodków w emigracyjnym poemacie Czesława Miłosza Gdzie wschodzi stońce $i$ kędy zapada, odtwarzającym z nostalgią jeszcze międzywojenne poczucie związku z odwieczną naturą Litwy, dokumentowane cytatem z wiersza Teodora Bujnickiego Litwo, ojczyzno moja... i podkreślone zamknięciem:

\author{
...bo nie zręczność ręki \\ Pisze poezje, ale wody, drzewa \\ I niebo, drogie nam, chociażby ciemne, \\ Które widzieli nasi rodzice i rodzice rodziców \\ I rodzice tych rodziców, od prawieka... ${ }^{10}$
}

Na podobnej przestrzenno-historycznej kanwie buduje się wileński regionalizm, dominujący w literaturze Wilna przed wystąpieniem żagarystów.

9 Świetnym przykładem nowoczesnej interpretacji zjawisk wielokulturowości Wilna na początku XX wieku jest rozprawa M. Kvietkauskasa, Polifonia literatury $w$ Wilnie okresu wczesnego modernizmu 1904-1915, Kraków 2012. Wydanie litewskie: Vilniaus literaturu kontrapunktai. Ankstyvasis modernizmas 1904-1915, Vilnius 2007.

10 Cz. Miłosz, Gdzie stońce wschodzi i kędy zapada, [w:] tenże, Wiersze, Kraków 1987, t. 2 , s. 244 
Miasto nasze żyje pod jarzmem tradycji - pisał Władysław Arcimowicz - Wszak to miasto Mickiewicza, Lelewela, ojca i syna Słowackich, Filomatów, Pola, Kraszewskiego, Syrokomli itd. [...] niemal każdy autor i dziennikarz wileński ugina się zawsze i wszędzie pod obowiązkiem nawiązywania do tradycji ${ }^{11}$.

Na takich podstawach kształtowała się powstająca wówczas i dominująca literatura regionalna. Jeszcze przed pierwszą wojną światową debiutowały późniejsze „regionalistki” (Helena Romer-Ochenkowska, Wanda Dobaczewska, Eugenia Kobylińska). Koncepcja wileńskiego „regionalizmu” wspierała się mocno na „tutejszości” i kultywowała z pietyzmem jej tradycje i obyczaje. Regionaliści uważali siebie za „historycznych” Litwinów, obywateli dawnego Wielkiego Księstwa Litewskiego, przy równoczesnej niechęci do Litwy „kowieńskiej”. Między regionalizmem w romantycznej tradycyjnej szacie a epigońskim naśladownictwem poezji modernistycznej zamykał się przeciętny ówczesny wzór wileńskiej twórczości. Ten stan rzeczy próbują przełamać dość nieśmiało młodzi poeci skupieni w Sekcji Twórczości Oryginalnej ogłaszający pod koniec lat dwudziestych zbiorowe tomiki wierszy: STO. Poezje, Z pod Arkad i Patykiem po niebie.

W tym kontekście należy umieścić uformowaną w roku 1931 wokół pisma „Żagary” (dodatku do konserwatywnego dziennika „Słowo”) grupę literackopublicystyczną. Jej powstanie wiązało się z wyraźnymi ambiwalencjami: między regionalizmem a uniwersalnością pogranicza, polskością a wieloetnicznością obszaru, konserwatyzmem a radykalizmem społecznym. Grupę literacką i pismo ,Żagary” tworzyli młodzi, urodzeni w okolicach 1910 roku wileńscy poeci i krytycy. Wszyscy oni byli wówczas albo studentami, albo niedawnymi absolwentami USB. Ich bunt pokoleniowy (o sobie, słowami Czesława Miłosza, pisali, iż są ,„przeklętym pokoleniem”) kierował się przeciw tradycjonalistycznemu i regionalistycznemu środowisku literackiemu Wilna, przeciw konserwatywnym i nacjonalistycznym poglądom niejako na przekór konserwatywnemu mecenasowi - redaktorowi „Słowa” Stanisławowi Catowi-Mackiewiczowi, reprezentując (piórami publicystów: Henryka Dembińskiego i Stefana Jędrychowskiego) idee radykalnie lewicowe, a w poezji - koncepcje awangardowe i katastroficzne.

11 W. Arcimowicz, Wilno literackie, „Tęcza” 1930, nr 25. 
Jak zauważył Aleksander Fiut, najwcześniejszy zarys programu „Żagarów” stanowił zapis w liście Czesława Miłosza do Jarosława Iwaszkiewicza z 1 lutego 1931 roku. Miłosz podkreślał, iż zadaniem pisma będzie:

1. wydobycie pierwiastków etnograficznych - przerobienie na twórczość naszej psychiki pół-Polaków, pół-Litwinów, pół-Ukraińców, wydobycie pierwiastków kresowych w ogóle, 2. propagowanie ekspansji kultury polskiej na wschód i wzajemnej penetracji kultur, 3. zwalczanie psychozy endeckiej ${ }^{12}$.

Już sam wybór tytułu czasopisma i w konsekwencji nazwa grupy podkreślają regionalizm o wyraźnie litewskim pochodzeniu. Nazwa miejscowa Żagary/ Żegary dość często pojawia się na terytorium Litwy oraz zachodniopółnocnej Wileńszczyzny i pochodzi od nazwy chrustu (patyków, gałęzi) używanych dla rozniecenia ogniska ${ }^{13}$. Zapewne nieprzypadkowo nazwa ta była bliska Miłoszowi, gdyż wieś Żegary była w bliskim sąsiedztwie Krasnogrudy. Siła przywiązania do przyjętej na początku nazwy sprawiła, że nawet zmieniając ją na „Piony”, po opuszczeniu „Słowa”, członkowie grupy zachowali w podtytule określenie: „Miesięcznik zespołu Żagarów”, a następnie w „trzeciej" samodzielnej fazie pisma powrócili do pierwotnej nazwy.

Jednak to właśnie żagaryści przeprowadzili najostrzejszy atak na wileński regionalizm. W imieniu „Młodego Wilna” - z właściwym dla siebie radykalizmem - wypowiedział się na ten temat Czesław Miłosz, który nieprzypadkowo od początku pozostawał w niezgodzie z prowincjonalną i zaściankową wizją Wilna. W artykule zamieszczonym w „Pionach” uznał regionalizm za ideę zdecydowanie szkodliwą ${ }^{14}$. Zdaniem żagarysty regionalizm, wypełniając życie umysłowe i artystyczne miasta, po pierwsze osłabia jego łączność z „kulturą reszty Polski”; z drugiej zaś miał - pozornie - łagodzić tarcia narodowościowe na Kresach.

12 Cyt. za: A. Fiut, Żagarysta w listach do skamandryty. (O korespondencji CzesławaMiłosza z Jarosławem Iwaszkiewiczem z lat 1930-1934), [w:] Żagary. Środowisko kulturowe grupy literackiej, red. T. Bujnicki, K. Biedrzycki, J. Fazan, Kraków 2009.

13 W 1931 roku korzystając z inicjatywy redaktora „Słowa” Stanisława Cata-Mackiewicza - rozpoczynają organizowanie zespołu redakcyjnego dodatku literackiego gazety. $\mathrm{Na}$ pierwszym zebraniu redakcji, w którym m.in. uczestniczyli Bujnicki i Jędrychowski, podjęto decyzję o nazwie pisma. Miało ono nosić tytuł „Żagary” dla podkreślenia związków regionalnych i ze względu na sens wyrazu oznaczającego chrust, patyki służące rozpaleniu ogniska.

14 Sens regionalizmu, ,Piony” 1932, nr 2, [w:] Przygody młodego umysh, Kraków 2003, s. $42-46$. 
Z tych potrzeb - dowodził - narodził się regionalizm jako środek wprowadzający do ziem wschodnich kulturę polską w dawkach mniej jaskrawych, w pigułkach sprzedawanych pod nazwami „tutejszości”, „kultury b. Księstwa Litewskiego”15.

\section{I dodawał:}

Regionalizm jest wyrazem nacjonalizmu, bądź płytkiego partykularyzmu. Miejscowe obyczaje, kulturę, a nie raz i jej zacofanie bierze regionalizm jako momenty dekoracyjne i sentymentalne, redukuje zagadnienie współżycia kultur narodowych do pewnych nastrojów i sentymentów [... $]^{16}$.

Jednak dla większości żagarystów odrębność pograniczna Wileńszczyzny stanowiła niepodważalny aksjomat: problem zarówno terytorialny, jak i pamięci historycznej. Na jej polskość językową i świadomościową nakładają się składniki białoruskie, litewskie, rosyjskie i inne. Szczególny zaś charakter mają historyczne odniesienia do tradycji Wielkiego Księstwa Litewskiego, które można powiązać z ideologią krajowców. To mogło mieć ważne konsekwencje kulturowe i etniczne. Charakteryzując środowisko ,żagarystów" w liście Do Tomasa Venclovy, pisał po latach Czesław Miłosz:

Zasadniczo powinniśmy byli uważać się za Litwinów o języku rodzinnym polskim - i kontynuować w nowych warunkach Mickiewicza "Litwo, ojczyzno moja”, co znaczyło by tworzyć literaturę litewską w języku polskim, jako równoległą do literatury litewskiej w litewskim. Ale przecie nikt tego nie chciał - ani Litwini, najeżeni obronnie wobec kultury polskiej jako wynaradawiającej, ani ci wszyscy mówiący po polsku, uważający się po prostu za Polaków i odnoszący się pogardliwie do „kłausiuków”, do narodu chłopów ${ }^{17}$.

Zatem wpływ na żagrystów miało nie tylko otoczenie polskie, lecz także wielonarodowe. Młodzi poeci nie działali w literackiej i kulturowej próżni.

15 Tamże, s. 43.

16 Tamże, s. 45.

17 Cz. Miłosz, Do Tomasa Venclovy, [w:] tenże, Zaczynając od moich ulic, Wrocław 1990, s. 36. 
Warto przy okazji wspomnieć, że w ówczesnym literackim Wilnie były reprezentowane nie tylko polskie środowiska; działali także twórcy żydowscy (słynna później grupa „Jung Wilne”18) oraz pisarze litewscy, białoruscy i rosyjscy. Były to zbiorowości w znacznym stopniu od siebie izolowane. Co ważne, próbę przełamania tych barier podjęli właśnie żagaryści, publikując na łamach pisma autorów innych narodowości, tłumacząc ich teksty oraz informując o wydarzeniach literackich i kulturalnych w tych środowiskach. Z zainteresowań dla kultury i literatury etnicznej Litwy i Białorusi tworzyło się szersze pojmowanie sytuacji pogranicznej, uwolnionej od nacisku nacjonalistycznych idei i wąsko pojmowanego regionalizmu.

Nie bez znaczenia było również miejsce urodzenia większości żagarystów. Czesław Miłosz urodził się w centrum etnicznej Litwy (Szetejnie w pobliżu Kiejdan); otoczenie białoruskie określało dzieciństwo i młodość Jerzego Putramenta, Józefa Maślińskiego, Leona Szredera i Jana Huszczy. Wilnianami byli Teodor Bujnicki i Aleksander Rymkiewicz. „Przybyszem” był jedynie Jerzy Zagórski, urodzony jednak również na „kresach”, w Kijowie. Wszyscy urodzeni w ostatnich latach zaborów dobrze znali język rosyjski oraz czytali literaturę rosyjską - dawną i współczesną. Znają - w większym lub mniejszym stopniu - język białoruski. Natomiast literaturę litewską dopiero poznają. Utrudnieniem była wyraźna odrębność językowa, która nawet dla urodzonego na Litwie Miłosza stanowiła barierę ${ }^{19}$. A jednak „litewskości” nie sposób wyeliminować z genezy „ZZagarów”. Nie tylko jako tradycji historycznej, lecz i przede wszystkim jako współczesności.

Żagaryści, inaczej niż regionaliści, postrzegali Wielkie Księstwo Litewskie przede wszystkim jako uznakowiony pejzaż. Dla jednych, jak na przykład dla urodzonych w Wilnie Teodora Bujnickiego czy Aleksandra Rymkiewicza, powracało ono jako połączony z sentymentem ważny aspekt pamięci historycznej. Tak jest na przykład w Pieśni o ziemi naszej Teodora Bujnickiego („Naucz się kochać Niemen, najpiękniejszą wstęgę / którą Stwórca przepasał pierś Wielkiego Księstwa [...]") czy w historiozoficznej wizji miasta w Rap-

18 Zob. J. Lisek, Jung Wilne - żydowska grupa artystyczna, Wrocław 2005.

19 Autorzy największej liczby przekładów z litewskiego, Czesław Miłosz i Teodor Bujnicki, korzystali z pomocy znających język litewski - Miłosz najprawdopodobniej Pranasa Ancevicusa, a Bujnicki żony Anny Stawskiej. 
sodzie wileńskim Rymkiewicza. Dla innych - na przykład dla Miłosza - litewski ,świat” folkloru i przyrody odzyskiwał swoją pierwotną suwerenność wobec historii (Jeszcze wiersz o Ojczyźnie). W mocno skonwencjonalizowany porządek tradycjonalistycznego przedstawiania motywów litewskich poważne zmiany wprowadzili zatem dopiero żagaryści. Ich zainteresowania dla kultury i literatury etnicznej Litwy wyrastały z niechęci do nacjonalizmu i wąsko pojmowanego regionalizmu. Te właśnie aspekty krajobrazu, przyrody, geograficznej przestrzeni, łączonych z pamięcią historyczną, stanowiły jeden z podstawowych czynników tworzących mityczny i literacki obraz terytorium. Geograficzna przestrzeń Wileńszczyzny stawała się przestrzenią koniecznego pojednania i zarazem uznania jej wielokształtności.

Heterogeniczność kultury wileńskiej wykorzystywali żagaryści, tworząc obrazy poetyckie o dużym stopniu uniwersalizacji. Operowali oni wielkimi planami historii, rozległymi, często egzotycznymi przestrzeniami, wizją katastroficzną. Baśniowość, mitologizacja, wizja kosmiczna i historiozoficzna organizowały świat przedstawiony ich utworów. Kształtowały także właściwą żagarystom symbolikę. Nie oznaczało to jednak zerwania ze światem własnym: środowiskiem i krajobrazem. Tak jest zarówno w wierszach Aleksandra Rymkiewicza i Jerzego Zagórskiego, jak też Czesława Miłosza i Teodora Bujnickiego. Jeszcze przed „Żagarami”, w wierszu Ojczyzna Bujnicki akcentował heterogeniczność przestrzeni należącej do rożnych wspólnot:

Bo te nieba wyblakłe, ta gleba nieżyzna,
Te chmurne listopady, ten radosny maj -
To jedyna dla serca i ducha ojczyzna,
Mniejsza czy białoruski, czy litewski kraj ${ }^{20}$.

Sięgnięcie po motywy pejzażowe wymagało więc autorskich decyzji; albo wpisanie się w zastany krajobrazowy stereotyp, albo sięgnięcie po nowe motywacje i nowe środki wyrazu. O związku pejzażu wileńskiego z poezją żagarystów pisał Wiesław Paweł Szymański: ,Związek ten jest [...] jednym z głównych kluczy do liryki żagarystów [...] nie była to jakaś nieokreślona przyroda,

20 STO. Poezje, Wilno 1928, s. 14. 
ale przyroda konkretna, ziemi wileńskiej..."21. Podobnie twierdził Stanisław Bereś, akcentując: „zbiorową fascynację Wileńszczyzną” jako istotny czynnik sprawczy obrazów artystycznych w utworach ,awangardy wileńskiej”22. Przedstawiana w tomikach Czesława Miłosza, Jerzego Zagórskiego, Teodora Bujnickiego, Jerzego Putramenta, Aleksandra Rymkiewicza, rozproszonych wierszach Józefa Maślińskiego i zbiorku (Ballada o podróżnych) „pogrobowca" żagarystów Jana Huszczy przestrzeń obejmuje wielorakie obszary regionu; „dzikie” krajobrazy natury: lasy, pola, mszary, rzeki i jeziora; przestrzenie kultury: wsie, miasteczka, dwory, sady i pola uprawne. Rzadziej pojawia się większy zespół urbanistyczny (z reguły jest to Wilno, inne miasta są dalekie i przez to egzotyczne; należą do innej obcej i nieznanej rzeczywistości). Ów różnorodny pejzaż Wileńszczyzny stawał się przedmiotem rozmaitych operacji: zbliżeń i oddaleń, typizacji i konkretyzacji, deskrypcji i wartościowania. Postrzegany jako pejzaż pierwotny i rodzący mity. Ukazywany w różnych porach dnia i roku, w zmiennych warunkach atmosferycznych, w zmieniających się barwach i oświetleniach, jest bogaty w wielorakie znaczenia i napięcia między człowiekiem i przyrodą. W znacznej części ma więc rację Piotr Kuncewicz, nazywając postawę żagarystów „przymierzem z ziemią"23. Dostrzec je można w dramatycznym spięciu Pieśni Miłosza, w której Chór odpowiada Annie: „Wszystko jest z ziemi poczęte ona jest doskonała”. Stosunek do rodzimego pejzażu wyrastał bowiem z niewątpliwej nim fascynacji oraz rzeczywistej pasji poznawania.

$\mathrm{Z}$ tym wszystkim motywy czysto litewskie występowały w poezji żagarystów dość rzadko; tym bardziej na uwagę zasługują dwa wiersze: napisany w wstępnej fazie działalności „Żagarów” i niewłączony później do żadnego zbiorku utwór Miłosza Jeszcze wiersz o ojczyźnie ${ }^{24}$ oraz wiersz Teodora Bujnickiego „Litwo. Ojczyzno moja...” przekształcający aluzję mickiewiczowską

21 W. P. Szymański, Neosymbolizm. O awangardowej poezji polskiej w latach trzydziestych, Kraków 1973, s. 202.

22 S. Bereś, Ostatnia wileńska plejada. Szkice o poezji kręgu Żagarów, Warszawa 1990, s. 98 .

23 P. Kuncewicz, ,Przymierze z ziemia” jako kategoria poetycka II Awangardy, [w:] tenże, Z problemów literatury polskiej XX wieku, t. II, Warszawa 1965.

24 „Żagary” 1931, nr 2, s. 2. 
w katastroficzną wizję przyrodniczego kataklizmu ${ }^{25}$. To charakterystyczne: w obu wierszach „ojczyzną” nie jest Polska. Owo, niewątpliwie wymierzone w oficjalne ideologie „państwowe”, akcentowanie litewskości przedstawianej przestrzeni wypełnia się odrębną semantyką własnego kraju. Czesław Miłosz w utworze Jeszcze wiersz o ojczyźnie „ojczyznę” - umieszcza poza pilnie strzeżonymi granicami państwowymi: „Nad brzegami niebieskiego Niemna / I Niewiaży o wodzie czarnej...” Ów niezwykły na tle wczesnej twórczości Miłosza sielankowy utwór, przedstawiający litewską Arkadię nad brzegami litewskich rzek, został opublikowany w 2 numerze „Żagarów”. Jego kontekst stanowiły dwa ostre i ciemne liryki Miłosza: Wiersze dla obłakanych i Wam.

Dla interpretatora ów fakt stanowi zaskoczenie: skąd ten pogodny nastrój, pełna radości i spokoju wizja świata? Odpowiedź może być jedynie hipotetyczna. Liryk przedstawia przestrzeń opuszczoną, etniczną Litwę odgraniczoną barierami politycznymi i silnie strzeżoną granicą. Ów świat rustykalny, „wieś spokojna i wesoła", której prace i zabawy powtarzają rytm przyrody i mieszczą się w litewskim folklorze (tańce na święta majowe - gegużynie), ale są niedostępne. Nie tylko ze względu na granicę. Także ze względu na utraconą prostotę i niewinność oraz obecność w innym okrutnym i skomplikowanym świecie. Nie każdy jest godny dostępu do tej przestrzeni, która - co ważne - mieści się w obszarze etnicznej Litwy.

Odniesienia historyczne i literackie przestrzeni ponadregionalnej, choć z regionem ściśle powiązanej, pojawiły się również w utworach Teodora Bujnickiego Pieśń o ziemi naszej oraz przywołanym wcześniej wierszu o incipicie „Litwo, ojczyzno moja...”. W tym wierszu, który może uchodzić za zsumowanie „doświadczeń” poetyckich grupy z pejzażem Wileńszczyzny jako pars pro toto historycznej Litwy, aluzję Mickiewiczowską poeta splótł z katastroficznym przeczuciem zagłady:

Litwo, ojczyzno moja. Żarliwe i prosto

Powtarzam słowa naszego pacierza.

Ziemio nieżyzna bławatków i ostów,

Białych kościołów na płaskich wybrzeżach [...]. 
Litwo [...]

Skrzywdzona przez stulecia i bóstwa,

Miecze z pochew obłoków wyszarp,

Sypnij gradem, niech potokiem chlusta,

Daj nam patos i ogień włóż w usta!

Cisza.

Krajobraz Litwy „skrzywdzonej” zamyka stwierdzenie niemożności wyzwolenia i buntu. Patetycznemu wezwaniu do ,żywiołów” odpowiada „cisza”, a więc gest „odmowy”. Inaczej kończył się pierwodruk tego wiersza, którego ostatni wers brzmiał: „Zapiał gdzieś kogut”. W tradycyjnej symbolice piania koguta - mieściła się bowiem nadzieja „świtu”, wezwanie do działania. $Z$ tej jednak wersji poeta zrezygnował.

Żagarystowska litewskość łączyła się ściśle z zainteresowaniem krajami bałtyckimi, ważnym nurtem badawczym na Uniwersytecie Stefana Batorego w Wilnie oraz - co szczególnie istotne - w powstałym w 1931 roku Instytucie Badań Europy Wschodniej26. Członkowie grupy „Żagary”, którzy studiowali na USB na przełomie lat dwudziestych i trzydziestych, musieli wielokrotne stykać się z tą problematyką. Dodajmy, że Akademicki Klub Włóczęgów Wileńskich (z którym byli związani Bujnicki, Miłosz, Jędrychowski i Maśliński) oraz organ Klubu „Włóczęga” wielokrotnie sięgali po tematykę „bałtycką”. Oddając się turystyce, poznawali coraz dokładniej przestrzenie białoruskie, łotewskie, estońskie i litewskie, których obrazotwórcza presja formowała później poetyckie pejzaże.

W miesięczniku „Włóczęga” znaleźć można wiele materiałów poświęconych krajom bałtyckim, głównie Litwie, ale także Łotwie i Estonii. W redakcyjnym artykule pisma w numerze 1 z 1935 roku z aprobatą przyjmowano koncepcję Michała Romera „solidaryzmu bałtyckiego" i godzono się na współodpowiedzialność za niekorzystny stan wzajemnych stosunków polskolitewskich.

26 Niektórych żagarystów łączyły z Instytutem Badań Europy Wschodniej więzi zawodowe (Teodor Bujnicki był sekretarzem Instytutu) oraz kontakty naukowo-dydaktyczne. Zwróćmy także uwagę na zastanawiającą zbieżność dat powstania Instytutu i pierwszego numeru „Żagarów”, który ukazał się w lipcu 1931 roku. 
Dlatego też - pisał anonimowy autor artykułu - myśląc o przyszłości Wilna, uważamy zawsze, że musi ono stać się ośrodkiem kulturalnym nie tylko dla miejscowej ludności polskiej, ale także dla sąsiednich państw bałtyckich oraz dla odrodzeńczego ruchu białoruskiego. Dlatego też z sympatią ustosunkowujemy się do wszystkich kulturalnych poczynań białoruskich na terenie naszego miasta. Bylibyśmy również dumni, gdyby w dziele tworzenia podstaw odrodzonej kultury narodowej litewskiej Wilno mogło współzawodniczyć z Kownem. Dlatego też chcielibyśmy, aby w Wilnie był większy odsetek Litwinów niż ten, który jest, a szczególnie by znalazły się w naszym mieście warsztaty pracy dla większej ilości inteligentów litewskich ${ }^{27}$.

Nie bez znaczenia jest fakt, że w „Włóczędze” Czesław Miłosz opublikował thumaczenia wierszy wybitnego litewskiego poety Kazysa Boruty (Żmudzini w więzieniu i Wilcze szczęście w n-rze 4 i Bunt oraczy w n-rze 6 z 1933 roku).

Także w „Żagarach” zagadnienia bałtyckie, aczkolwiek nie dominujące, znalazły swoje odzwierciedlenie tak w twórczości, jak i publicystyce. Ze zrozumiałych względów (kulturowych i politycznych) uwaga piszących skupiała się głównie na Litwie. W ostatniej, trzeciej fazie „Żagarów” (lata 1933-1934) problematyka ta doszła najwyraźniej do głosu, a jej zwieńczeniem był osobny „litewski” numer pisma.

W numerze poprzednim (22 z 1933 roku) żagaryści (Teodor Bujnicki i Czesław Miłosz) wykreowali żartobliwą postać „,amalgamat Litwina i Żyda” - Arona Pirmasa ${ }^{28}$.

Pirmas pojawiał się nie tylko na łamach ,Żagarów”, lecz także - aż do roku 1940 w prasie wileńskiej, a pod pseudonimem ukrywali się - poza wymienionymi - Maśliński, Putrament, Huszcza i inni.

Numer „litewski” był próbą przerzucania pomostów między literaturami obu krajów. Redakcja opatrzyła swoje przedsięwzięcie znamiennym komentarzem:

27 W poszukiwaniu syntezy, „Włóczęga” 1935, nr 1, s. 3.

28 „Aron Pirmas. Postać fikcyjna stworzona jako żart Teodora Bujnickiego i mój. Bujnicki pamiętał o Koźmie Prutkowie, poecie wymyślonym przez paru rosyjskich literatów. «Pirmas» znaczy po litewsku pierwszy, więc nazwisko znaczy Aron Pierwszy. Aron Pirmas ogłaszał wiersze w «Żagarach» [....] Inni też pod tym nazwiskiem pisali» (Cz. Miłosz, Abecadło Miłosza, Kraków 1997, s. 43). 
Wydajemy numer litewski „Żagarów” w chwili najmniej może odpowiedniej. Absurdalność tego stanu rzeczy, który istnieje od lat kilkunastu w stosunkach polsko-litewskich kumuluje znowu w postaci fali bezmyślnych represji.

Wiemy jednak, że kulturę narodu tworzą nie ci, którzy autorytet swój utrzymują jedynie przy pomocy więzień i wrzasku durnych studentów.

Litwa oceni ich kiedyś w sposób właściwy ${ }^{29}$.

W numerze - poza autorami polskimi - bardzo licznie byli reprezentowani Litwini, zarówno mieszkający w Wilnie, jak i na Litwie „kowieńskiej”. Była to niewątpliwie udana próba przełamania izolacjonizmu w stosunkach narodowościowych. Szczególne znaczenie miało zwrócenie się do wileńskich Litwinów, ograniczanych przez ówczesną polską administrację. Mimo to podejmują oni zdecydowaną ,pracę organiczną”, skierowaną na umocnienie własnego języka i własnej kultury. Dążą do rozwinięcia szkolnictwa (m.in. wileńskiego gimnazjum Witolda Wielkiego, wokół którego skupia się ówczesna inteligencja litewska), powołują stowarzyszenia kulturalno-literackie. W wychodzących w Wilnie pismach litewskich (m.in. „Kelias”, „Vilnaus Varpas”, „Vilniaus Żodis” z dodatkiem „Kuryba ir Kritika”, „Lietuviszkas Baras”) zamieszczają swoje utwory i teksty publicystyczne: Rafał Mackiewiczus (Mackonis), Józef Konopka, Anna Mieczutie, Antoni Wałajtis, Hieronim Cycenas, Albin Żukauskas, Józef Kieksztas (Adomawiczus) i inni. Obok twórczości oryginalnej w języku litewskim, prowadzą oni ożywioną działalność krytycznoliteracką i przekładową. O tym środowisku pisał w numerze trzecim „Śród Literackich” Włodzimierz Sakowicz:

Starsze pokolenie pisarzy Litwinów (wileńskich), które cierpiało kiedyś na kłopoty pióra zamilkło, gdyż nie ma nic do powiedzenia. Natomiast młodsza generacja pisarzy, bardziej świadoma swego powołania i do tego mocno związana z krajem, z którego ród swój wywodzi, pracując usilnie bogaci literaturę litewską (wileńską), co prawda więcej może ilościowo niż jakościowo ${ }^{30}$.

29 „Żagary” 1934, nry 24-25, s. 1.

30 W. Sakowicz, Życie literackie wśród Litwinów wileńskich, „Środy Literackie” 1936, z. 3 , s. 40 . 
Pisarze litewscy znali - rzecz jasna - dobrze język polski (na przykład Anna Maczutie studiowała polonistykę na USB), ale świadomie unikali prób literackich w języku polskim. Starali się go natomiast wykorzystać dla działań informacyjnych i propagujących literaturę i kulturę litewską wśród życzliwie nastawionych wobec niej Polaków. Stąd ważna rola informatorów litewskich w kronikach i artykułach przeglądowych umieszczanych w „Źródłach Mocy”, „Żagarach” czy później w „Środach Literackich”. Ich autorami byli wzmiankowani wcześniej: Heronim Cycenas i Włodzimierz Sakowicz. Krytykę artystyczną na łamach „Słowa”, „Kuriera Wileńskiego” i „Przeglądu Wileńskiego” uprawiał czołowy malarz litewski zamieszkały w Wilnie Witold Kajruksztis. W „Żagarach” te ograniczenia zostały przełamane. W „litewskim” numerze „Żagarów" zamieszczono nie tylko thumaczenia (między innymi fragmenty poematu Krzysztofa Duonelaitisa Cztery pory roku i Kazysa Boruty Wyszedt aby stońce na plecach przynieść), lecz także napisane przez wileńskich Litwinów artykuły przeglądowe: Antanasa Wałajtisa Nowe prady w literaturze litewskiej, Władysława Dremy Wspótczesna sztuka litewska, Notatnik etnografa Hieronima Cycenasa. W numerze znalazły się jeszcze publikacje o litewskich pieśniach ludowych, roli Wilna w lituanistyce polskiej i fragment prozy Antanasa Venclowy.

Nieprzypadkowo w drukowanej w „Żagarach” Rozmowie o literaturze sygnowanej przez Arona Pirmasa anonimowy interlokutor Litwin wypowiada następującą opinię:

Piszecie o Litwie, o jej kulturze i sztuce. 0 , to jest niebezpieczne. Ściągniecie na swoją głowę wymyślania i potępienia. Nasi dziennikarze natychmiast nazwą was polskimi imperialistami, robiącymi krecią robotę. Wasza rzekoma sympatia do Litwy - to perfidia chytrych Polaków - tak powiedzą ${ }^{31}$.

A więc siła obu nacjonalizmów jest poważną groźbą dla procesu porozumienia. Stąd dalsze pytania i odpowiedzi wywiadu starają się sprecyzować nie tylko specyficzne cechy ówczesnej litewskiej literatury, lecz również zwrócić uwagę na podobieństwa z literaturą polską. Prowadzący wywiad (Czesław Miłosz) tak dookreśla swoje zainteresowanie poezją Kazysa Boruty:

31 A. Pirmas (Czesław Miłosz i Pranas Ancevicus), Rozmowa o literaturze, „Żagary” 1934, nr 24-25. 
Pytałeś mnie kiedyś, dlaczego podobają się wiersze Kazysa Boruty. Otóż Boruta został wierny swojemu pochodzeniu i odpory jest na wszelką importowaną kulturę. Jest prymitywny, ale właśnie dzięki temu szczeremu prymitywizmowi wywiera wrażenie. Inni ulegający różnym izmom wyglądają tak dziwacznie jak murzyni ubrani w futra.

Dalej Miłosz określa Borutę jako „majstra pierwszorzędnego, który jak nikt czuje język” i wskazuje na podobieństwa z Jesieninem. Właśnie owe łączenie motywów rustykalnych z ideą radykalizmu i rewolucjonizmu wyraźnie odpowiadało żagarystom tak silnie akcentującym powiązanie krajobrazu $\mathrm{z}$ aspektami społecznymi.

Aktywność „litewska” żagarystów nie zamknęła się wraz z ostatnim numerem pisma. Na łamach „Kuriera Wileńskiego”, „Słowa”, „Śród Literackich” i innych publikowali oni zarówno tłumaczenia litewskich pisarzy, jak i szerzej omawiali ówczesną litewską literaturę. Teodor Bujnicki i Pranas Ancevicus (Franciszek Ancewicz) ogłosili w Kolumnie Literackiej „Kuriera Wileńskiego" dwuczęściowe omówienie przekładów Władysława Abramowicza (krytycznie) i Karjuksztisowej (z uznaniem).

Wizytę polskich twórców na Litwie po otwarciu granicy w 1939 roku przedstawiał szerzej Józef Maśliński. W „Kurierze Wileńskim” w latach 1937-1939 Teodor Bujnicki, Józef Maśliński i Aron (Ariel) Pirmas (!) publikują tłumaczenia wierszy: Salomei Neris, Kazysa Boruty, Antoniego Rymidisa, Jana KossuAleksandrawicziusa, Józefa Tysliavy, Antoniego Miszkinisa. Finałem zaś były artykuły i tłumaczenia z litewskiego w „Gazecie Codziennej” i „Kurierze Wileńskim” w latach 1939-1940 po wcieleniu Wilna w obręb litewskiego państwa. W „Kurierze” (18 lutego 1940 roku) pojawia się szkic Ariela Pirmasa (prawdopodobnie pióra Józefa Maślińskiego) Współczesna poezja litewska, a „Gazeta Codzienna” w jednym z ostatnich numerów zamieszcza artykuł Teodora Bujnickiego Literaturze litewskiej należny rewanż ${ }^{32}$, który można uznać za podzwonne wcześniejszych działań poetów - żagarystów. Wskazując na niewspółmierność tłumaczeń w obu językach, Bujnicki wskazywał na to, iż ,[... najlepszą drogą do zbliżenia narodów jest poznanie ich dorobku kulturalnego, spotkanie się w dziedzinie, której obce są wszelkie porachunki, gniewy i żale”. 
I wyrażał nadzieję:

Możliwości realizacji tych zadań spoczywają dziś w ręku właśnie pisarzy wileńskich; oczywiście mają przed sobą oni ogromną trudność do przezwyciężenia: język, o którego nieznajomość rozbijały się dotychczasowe dobre intencje wydawców i redaktorów [...] Należy mieć nadzieję, iż ten stan rzeczy dziś ulegnie poprawie; że przyszły tłumacz nie uroni nic z surowej, prostej piękności Czterech pór roku Krystiana Donelaitisa, że zapozna nas z wierszami Boruty, Neris, Miszkinisa, Giry, z dorobkiem ciekawej i egzotycznej nieraz dla nas beletrystyki litewskiej. Warto też będzie pomyśleć o przyswojeniu niektórych pozycji dramaturgii litewskiej. [...] Nie będzie to próbą „wkradania się w łaski” literatury litewskiej, ale słuszny i aktualny rewanż.

Na wykonanie zadania było już za późno. Upadek republiki litewskiej, rozproszenie najlepiej przygotowanych do tej roli byłych żagarystów uniemożliwiły zarysowany w artykule szeroki program. W rezultacie pozostał niewielki, ale jednak znaczący dorobek przekładowy.

Litewski „epizod” z Litwą części żagarystów miał dla nich istotne znaczenie. Podkreślał z jednej strony pograniczny charakter kultury literackiej obszaru Wilna i Wileńszczyzny, był zasadniczym sprzeciwem wobec ograniczonej wykładni regionalizmu oraz agresywnego nacjonalizmu. Z drugiej - problematyce litewskiej nadawał sens scalający - łączył wieloimienność kulturową i etniczną w sensualistycznym obrazie świata przyrody wypełnionej znaczeniami o różnym pochodzeniu.

\section{Bibliografia}

Arcimowicz W., Wilno literackie, „Tęcza” 1930, nr 25.

Bardach J., O dawnej i niedawnej Litwie, Poznań 1988.

Bereś S., Ostatnia wileńska plejada. Szkice o poezji kręgu Żagarów, Warszawa 1990.

Dobaczewska W., Dzieje kultury wileńskiej pomiędzy dwoma powstaniami, Wilno 1937. 
Dobaczewska W., Słowiki litewskie, „Środy Literackie” 1936, nr 5, s. 19.

Kuncewicz P., "Przymierze z ziemią" jako kategoria poetycka II Awangardy, [w:] tenże, Z problemów literatury polskiej XX wieku, t. II, Warszawa 1965.

Kurzowa Z., Język polski Wileńszczyzny i kresów północno-wschodnich XVI-XX w., Warszawa-Kraków 1993.

Lapinskene A., Vilniaus lietuviu literatura 1920-1940, Vilnius 2008.

Miłosz Cz., Do Tomasa Venclovy, [w:] tenże, Zaczynając od moich ulic, Wrocław 1990, s. 36.

Pirmas A. (Czesław Miłosz i Pranas Ancevicus), Rozmowa o literaturze, „Żagary" 1934, nr 24-25.

Sakowicz W., Życie literackie wśród Litwinów wileńskich, „Środy Literackie” 1936, z. 3, s. 40 .

STO. Poezje, Wilno 1928.

Szymański W. P., Neosymbolizm. O awangardowej poezji polskiej w latach trzydziestych, Kraków 1973. 